\title{
Article \\ Nutritional, Sensory, Texture Properties and Volatile Compounds Profile of Biscuits with Roasted Flaxseed Flour Partially Substituting for Wheat Flour
}

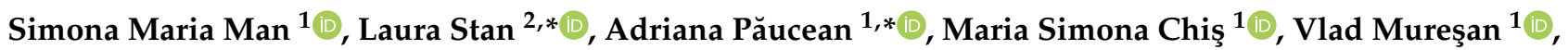 \\ Sonia Ancuţa Socaci ${ }^{2}$ (D), Anamaria Pop ${ }^{1}$ (D) and Sevastiţa Muste ${ }^{1}$ \\ 1 Department of Food Engineering, Faculty of Food Sciences and Technology, University of Agricultural \\ Sciences and Veterinary Medicine of Cluj-Napoca, 3-5 Mănăştur Street, 400372 Cluj-Napoca, Romania; \\ simona.man@usamvcluj.ro (S.M.M.); simona.chis@usamvcluj.ro (M.S.C.); vlad.muresan@usamvcluj.ro (V.M.); \\ anamaria.pop@usamvcluj.ro (A.P.); sevastita.muste@usamvcluj.ro (S.M.) \\ 2 Department of Food Sciences, Faculty of Food Sciences and Technology, University of Agricultural Sciences \\ and Veterinary Medicine of Cluj-Napoca, 3-5 Mănăştur Street, 400372 Cluj-Napoca, Romania; \\ sonia.socaci@usamvcluj.ro \\ * Correspondence: laurastan@usamvcluj.ro (L.S.); adriana.paucean@usamvcluj.ro (A.P.)
}

\section{check for}

updates

Citation: Man, S.M.; Stan, L.; Păucean, A.; Chiş, M.S.; Mureşan, V.; Socaci, S.A.; Pop, A.; Muste, S. Nutritional, Sensory, Texture Properties and Volatile Compounds Profile of Biscuits with Roasted Flaxseed Flour Partially Substituting for Wheat Flour. Appl. Sci. 2021, 11, 4791. https://doi.org/10.3390/ app11114791

Academic Editor: Silvia Mironeasa

Received: 27 April 2021

Accepted: 21 May 2021

Published: 23 May 2021

Publisher's Note: MDPI stays neutral with regard to jurisdictional claims in published maps and institutional affiliations.

Copyright: (c) 2021 by the authors. Licensee MDPI, Basel, Switzerland. This article is an open access article distributed under the terms and conditions of the Creative Commons Attribution (CC BY) license (https:// creativecommons.org/licenses/by/ $4.0 /)$.

\begin{abstract}
The study aimed at assessing effects of partial replacement (0-40\%) of wheat flour with roasted flaxseed flour (RFSF) on the quality attributes of biscuits. Nutritional, antioxidative, volatile and sensory properties, as well as texture analysis and the contents of macroelements and microelement were studied. Increasing RFSF content in biscuits resulted in a significant increase $(p<0.05)$ in protein (from $8.35 \%$ to $10.77 \%$ ), fat (from $15.19 \%$ to $28.34 \%$ ) and ash (from $1.23 \%$ to $2.60 \%$ ) while the hardness and spread factor of the biscuits decreased with the increased level of roasted flaxseed flour. Moreover, the addition of $40 \%$ RFSF registered a positive influence on the fibre content of the final baked biscuits, increasing its value about 6.7 -fold than in the control sample. Total phenolic content, antioxidant activity and biscuits' aroma volatile profile increased their amounts with RFSF addition. The nutritional, textural and sensorial results of the present study demonstrated that $25 \%$ RFSF could be added in the biscuits manufacturing without affecting the biscuits aftertaste, offering promising healthy and nutritious alternative to consumers.
\end{abstract}

Keywords: roasted flaxseed flour; GC/MS; aroma; antioxidant activity; sensory evaluation; fiber; macro and microelements; biscuits

\section{Introduction}

Bakery and pastry products are consumed worldwide in large quantities on a daily basis and play an important role in human nutrition. Among bakery products, biscuits are the most popular amongst consumers as a rich source of carbohydrates and fats, but low in proteins and dietary fibers along with quite a good shelf life [1]. Generally, biscuits are made with refined wheat flour which is deficient in some essential amino acids (lysine, tryptophan, threonine, methionine and histidine) and other nutrients (fiber, minerals and vitamins) [2-4]. Nowadays there is a high demand for high nutritional value foods. In the current Western society's diet, the intake of $\omega-6$ fatty acids is generally higher compared to the intake of $\omega-3$ fatty acids and this leads to unfavorable nutritional consequences. Therefore, there is a need on the market for innovative products that meet the nutritional requirements of consumers. Some authors suggest that diet supplementation with flaxseed (Linum usitatissimum) offers potential health benefits in cases like cardiovascular risk, severe hyperlipidemia, certain types of cancers and other metabolic disorders [5-9]. Flaxseed contain protein $(20 \mathrm{~g} / 100 \mathrm{~g})$, dietary fiber $(28 \mathrm{~g} / 100 \mathrm{~g})$, fat $(41 \mathrm{~g} / 100 \mathrm{~g})$, moisture $(6.5 \mathrm{~g} / 100 \mathrm{~g})$, minerals $(2.4 \mathrm{~g} / 100 \mathrm{~g})$ and carbohydrates $(28.9 \%)$, being recognized as an important oilseed and fiber crop [10-12]. It ought to be emphasized that the linseed chemical composition 
may vary depending on the genetic characteristics, growing conditions and crop management practices. Furthermore, flaxseed has a unique fatty acid profile. It is high in polyunsaturated fatty acids ( $73 \mathrm{~g} / 100 \mathrm{~g}$ of total fatty acids), moderate in monounsaturated fatty acids $(18 \mathrm{~g} / 100 \mathrm{~g})$, and low in saturated fatty acids $(9 \mathrm{~g} / 100 \mathrm{~g})$. The content of linoleic acid is about $16 \mathrm{~g} / 100 \mathrm{~g}$ of total fatty acids while $\alpha$-linolenic acid (ALA) reaches about $57 \mathrm{~g} / 100 \mathrm{~g}$ [13]. Tocopherols (20-70 mg/100 g) and carotenoids ( $5.7 \mathrm{mg} / 100 \mathrm{~g})$ are also found in flaxseed oil, therefore flaxseed is considered an important ancient medicine and functional food ingredient [14].

Flaxseed is one of the most important oilseed crops for industrial as well as for food and feed purposes, being part of the human diet for thousands of years, and more recently it has been used as a source of nutraceuticals $[10,11,15]$. The bioactive components in flaxseed that provide health benefits include $\alpha$-linolenic acid, lignans and dietary fiber $[16,17]$, proteins and soluble mucilage $[8,11,16,18-21]$. The flaxseed mucilage may be considered a food hydrocolloid due to its composition, which consists of a mixture of neutral arabinoxylans and acidic rhamnose-containing polysaccharides [22]. Evenmore, antioxidant activity of the lignans and the presence of different types of phenolic compounds such as phenolic acids, flavonoids, phenylpropanoids and tannins [23] may reduce the risk of cardiovascular diseases and contribute to the anticancer activity [12,24-26], particularly hormone-dependent cancers such as prostate and breast [27].

The behavior of proteins in a food system is affected by their techno-functional properties which are mainly dependent on the following factors: the structure of the protein, their hydration mechanisms for solubility and water or oil retention capacity, rheological characteristics for viscosity and gelation, and their interfacial properties for emulsions and foams [28]. Flaxseed proteins have real potential to be used as techno-functional food ingredient in several food products particularly in breads, meat emulsions, and sauces [26]. Thus, flaxseed can be incorporated into diet as ground flaxseed or flaxseed oil. Flaxseed was previously incorporated in various bakery products such as cookies and biscuits [26,29-33] bread $[13,22,34,35]$ and cakes $[15,36]$. The results of these studies showed that a substitution levels up to $20 \%$ led to good product acceptability [29].

Consumers' trend to seek nutritional foods with remarkable value in the diet is highly directed toward the use of flaxseed as a potential ingredient in foods. The nutrient profile of flaxseed biscuits is a valued option, especially for consumers interested in healthy snack diversification.

The aim of this study was to examine the effects of partial replacement of wheat flour with roasted flaxseed flour on the quality attributes of biscuits, with special attention on their nutritional proprieties and volatile profile. Wheat flour substitution with flaxseed flour in biscuits formulation proposed in this study can be an example of successful collaboration between research and food industry and are in agreement with the confectionery products trends.

\section{Materials and Methods}

\subsection{Materials}

All the ingredients used in the biscuit formulations were bought from the local market in Cluj-Napoca, România. The wheat flour (WF) sample was produced by a local mill (Boromir, Deva, Romania) and sold as type 000 according to its ash content following the Romanian classification [37] ( $0.48 \%$ ash content and $29.57 \%$ wet gluten). Flaxseeds originating from Ukraine were used to prepare the flaxseed flour as described further. Initially, flaxseeds were roasted at $180^{\circ} \mathrm{C}$ for $15 \mathrm{~min}$, then cooled and ground on a GM200 laboratory mill (Grindomix, Retsch $\mathrm{GmbH}$, Haan, Germany) at 10,000 rotations/min for $50 \mathrm{~s}$. To ensure the uniformity of particles, the roasted flaxseed flour (RFSF) was sieved through a $0.8 \mathrm{~mm}$ sieve. Four blends of various ratios of both flours were used to prepare the biscuits, as presented in Section 2.2.2. 


\subsection{Methods}

\subsubsection{Proximate Composition Analysis}

The chemical characteristics were determined using the AACC (2000) methods [38]. Wheat flour (WF), roasted flaxseed flour (RFSF), control biscuits and RFSF incorporated biscuits were analysed for moisture (AACC 44-15.02, 2000), ash (AACC 08-01.01, 2000), fat (AACC 30-25.01, 2000), crude fiber (AACC 32-07.01, 2000). The proteins were measured using the Kjeldahl method (AACC 46-11.02, 2000) using the nitrogen to protein conversion factor of 5.7. Total carbohydrate (\%) content was calculated according to Equation (1) according to methods reported by Man et al. [39]:

$$
\text { Total carbohydrates }(\%)=100-[\text { moisture }(\%)+\operatorname{ash}(\%)+\operatorname{proteins}(\%)+\operatorname{lipids}(\%)+\operatorname{crude} \text { fiber }(\%)]
$$

All determinations were made in triplicate.

\subsubsection{Preparation of Biscuits}

First step was to formulate the four flour blends (100:0, 90:10, 75:25 and 60:40 WF:RFSF, $\mathrm{w}: \mathrm{w})$. The flour blends were stored in air-tight containers until further use. The second step was premixing margarine ( $60 \%$ fat) with powdered sugar into a cream base and then mixing that with the flours, instant whole milk powder ( $26 \%$ fat and $26 \%$ protein), sodium bicarbonate, vanilla essence and water. The doughs were mixed for seven min in a mixer (KitchenAid ${ }^{\circledR}$ Precise Heat Mixing Bowl, Greenville, OH, USA), at medium speed. Mixing, resting and baking technological parameters are listed in Table 1. The control sample was prepared using the same procedure, but omitting the flaxseed. The dough was rolled out into circular shapes of $0.4 \mathrm{~cm}$ thickness and then the biscuits were shaped by stamping with cylindrical shapes into $5.5 \mathrm{~cm}$ diameter. After baking (Zanolli oven, Verona, Italy) all biscuits samples were removed from the trays for cooling, then packed in polypropylene bags and sealed until further analysis. Biscuit samples were coded as B0, B10, B25 and $\mathrm{B} 40$, respectively, taking into consideration the amount of $\operatorname{RFSF}(0 \%, 10 \%, 25 \%, 40 \%)$ as shown in Table 1. Each batch of biscuits was made the day before the sensory, texture and volatile analysis.

Table 1. Ingredients and technological parameters used in the preparation of biscuits.

\begin{tabular}{|c|c|c|c|c|}
\hline \multirow{2}{*}{ Ingredients (g) } & \multicolumn{4}{|c|}{ Biscuits Samples* } \\
\hline & B0 & B10 & B25 & B40 \\
\hline Wheat flour (WF) & 100 & 90 & 75 & 60 \\
\hline Roasted flaxseed flour (RFSF) & - & 10 & 25 & 40 \\
\hline Powder milk ** & 20 & 20 & 20 & 20 \\
\hline Margarine $* *$ & 40 & 40 & 40 & 40 \\
\hline Sugar powdered ** & 40 & 40 & 40 & 40 \\
\hline Sodium bicarbonate ${ }^{* *}$ & 2.5 & 2.5 & 2.5 & 2.5 \\
\hline Vanilla essence $* *$ & 0.5 & 0.5 & 0.5 & 0.5 \\
\hline Water ** & 25 & 25 & 25 & 25 \\
\hline \multicolumn{5}{|c|}{ Technological parameters } \\
\hline Mixing time (min) & 7 & 7 & 7 & 7 \\
\hline Dough temperature $\left({ }^{\circ} \mathrm{C}\right)$ & 22 & 22.4 & 23 & 23.5 \\
\hline Resting time (min) & 60 & 60 & 60 & 60 \\
\hline Temperature $\left({ }^{\circ} \mathrm{C}\right)$ & $3-4$ & $3-4$ & $3-4$ & $3-4$ \\
\hline Baking time (min) & 10 & 10 & 10 & 10 \\
\hline Temperature $\left({ }^{\circ} \mathrm{C}\right)$ & 200 & 200 & 200 & 200 \\
\hline
\end{tabular}

Note: ${ }^{*}$ B0 $=0 \%$ biscuits with 100\% wheat flour (control sample); B10 = biscuits with 10\% RFSF; B25 = 25\% biscuits with $25 \%$ RFSF; B40 = biscuits with $40 \%$ RFSF. ${ }^{* *}$ The auxiliar materials are reported to $100 \%$ of flour blends. 


\subsubsection{Macro- and Microelements}

Macro- and microelements were determined by atomic absorption spectrophotometry (AAS), according to the methods described by Păucean et al. [40] and Chiş et al. [41]. Briefly, $3 \mathrm{~g}$ of biscuits were burned at $550{ }^{\circ} \mathrm{C}$ in the furnace for $10 \mathrm{~h}$ (Nabertherm B150, Lilienthal, Germany). The ash was dissolved in $\mathrm{HCl} 20 \%$ and made up to a final volume of $20 \mathrm{~mL}$ in a volumetric flask. The macroelements $(\mathrm{K}, \mathrm{Ca}, \mathrm{Mg})$ and microelements $(\mathrm{Fe}, \mathrm{Cu}, \mathrm{Zn}$ and $\mathrm{Mn}$ ) were determined by AAS (Varian 220 FAA instrument, Mulgrave, Victoria, Australia). Mixed standard solutions with $\mathrm{P}, \mathrm{K}, \mathrm{Cu}, \mathrm{Zn}, \mathrm{Fe}, \mathrm{Mn}, \mathrm{Ca}, \mathrm{Mg}$ (ICP Multielement Standard solution IV CertiPUR) were purchased from Merck (Merck KGaA, Darmstadt, Germany). All chemicals and solvents used in this study were of analytical grade. The results were expressed related to the weight of the fresh biscuits.

\subsubsection{Physical Evaluation of Biscuits}

The diameter of six biscuits placed edge to edge was measured with a Vernier caliper (0.01 $\mathrm{mm}$ accuracy). The average diameter in centimetres was calculated by dividing [42] the value by six [4]. Similarly, the mean thickness of the biscuits was measured by stacking 6 biscuits on top of each other and dividing the value by six. For the spread factor the diameter was divided by thickness. The weight of the biscuits was measured on an analytical balance and calculated as the mean value of the weight of four individual biscuits.

\subsubsection{Total Phenolics Content}

Total polyphenols content and antioxidant activity were determined as described by Bunea et al. [43] with slight modifications as proposed by Chis et al. [44]. Briefly, one gram of biscuit sample was extracted three times with $100 \mathrm{~mL}$ acidified methanol (85:15 $\mathrm{v} / \mathrm{v}$, $\mathrm{MeOH}: \mathrm{HCl}$ ) by maceration under continuous stirring (magnetic stirrer, Velp Scientifica, Usmate Velate, Italy) for $24 \mathrm{~h}$. Total phenolics content of the extracts was determined spectrophotometrically (Folin-Ciocalteu method). Thus, in a $100 \mathrm{~mL}$ volumetric flask, $10 \mathrm{~mL}$ of methanolic extract was mixed with $5 \mathrm{~mL}$ of Folin-Ciocalteu's reagent; $5 \mathrm{~mL}$ of $7.5 \%$ sodium carbonate solution was added. Distilled water was used to fill up the flask until the graduation marking. Samples were kept in the dark for $90 \mathrm{~min}$, and then, absorbance was read at $760 \mathrm{~nm}$ on a model 1700UV/VIS spectrophotometer (Shimadzu Scientific Instruments, Kyoto, Japan).

\subsubsection{DPPH Radical Scavenging Activity Assay}

The radical scavenging activity was determined spectrophotometrically by the 2,2diphenyl-1-picrylhydrazyl (DPPH) method as described by Păucean et al. [40]. The phenolic extracts $(0.1 \mathrm{~mL})$ were mixed with DPPH solution $(3.9 \mathrm{~mL})$, kept in the dark at ambient temperature for $30 \mathrm{~min}$. The absorbance of the mixtures was recorded at $515 \mathrm{~nm}$ (1700 UV/VIS spectrophotometer Shimadzu) against a methanol blank. Negative control was prepared using $0.1 \mathrm{~mL}$ methanol and $3.90 \mathrm{~mL}$ of DPPH. The radical scavenging activity was calculated according to the following Equation (2):

$$
R S A[\%]=\frac{A b s_{D P P H}-A b s_{\text {sample }}}{A b s_{D P P H}} \times 100
$$

where $A b s_{D P P H}=$ absorbance of DPPH solution and $A b s_{\text {Sample }}=$ absorbance of the sample.

\subsubsection{Volatile Compounds}

Qualitative analyses of the volatile compounds were achieved using "in-tube extraction" coupled with gas-chromatography mass spectrometry (ITEX/GC-MS, Shimadzu GC-MS model QP-2010) [45]. Three grams of each sample were weighed into a $20 \mathrm{~mL}$ sealed-cap headspace vial and incubated for $30 \mathrm{~min}$ at $70{ }^{\circ} \mathrm{C}$ with continuous agitation. The volatile compounds from the gaseous headspace of the sample were repeatedly adsorbed onto a microtrap (ITEX-2TrapTXTA, TA 80/100 mesh, Tenax, Zwingen, Switzerland) using 
a CombiPAL AOC-5000 autosampler (CTC Analytics, Zwingen, Switzerland). The volatile compounds were further thermally desorbed into the injection port of the GC-MS QP2010 system and separated on a ZB-5 ms column of $30 \mathrm{~m} \times 0.25 \mathrm{~mm}$ i.d. and $0.25 \mu \mathrm{m}$ film thickness (Phenomenex, Torrance, CA, USA). The column oven temperature program was set initially at $40{ }^{\circ} \mathrm{C}$ (kept at this temperature for $6 \mathrm{~min}$ ) and then increased to $50{ }^{\circ} \mathrm{C}$ at $2{ }^{\circ} \mathrm{C} / \mathrm{min}$, followed by an increase to $240{ }^{\circ} \mathrm{C}$ at $7{ }^{\circ} \mathrm{C} / \mathrm{min}$ (kept at this temperature for $5 \mathrm{~min}$ ). The temperatures of the ion source, injector, and interface were set at $250{ }^{\circ} \mathrm{C}$. The carrier gas was helium at a flow rate of $1 \mathrm{~mL} / \mathrm{min}$. The split ratio was 1:2. The MS detector was operated in the EI mode, using a scan acquisition mode in the range of 40-400 m/z. Mass spectra was identified by comparison with a series of standard alkanes-alkane standard solution.

The identification of volatile compounds was performed by comparing their mass spectra with those in the NIST27 and NIST147 libraries and by retention indices drawn from [46,47] (for columns with a similar stationary phase to ZB-5 ms). Afterwards, the mass spectra values were compared and verified with the retention indices drawn from Pherobase [46] and Flavornet [47] databases. The results were expressed as relative percentage of the total peaks area.

\subsubsection{Instrumental Analysis of Texture}

The textural properties of the biscuits were measured with a CT 3 Texture Analyzer (Brookfield Engineering Labs, Middleboro, MA, USA), equipped with a $10 \mathrm{~kg}$ load cell and the $6 \mathrm{~mm}$ cylindrical probe (TA41). The textural properties were determined as described by Pop et al. [48] with slight modifications. A compression test was applied to all samples ( $5 \mathrm{~mm}$ target distance, $3 \mathrm{~mm} / \mathrm{s}$ test and post-test speed, trigger load $5 \mathrm{~g}$ ). The Brookfield Engineering Labs Texture Pro CT V1.6 software was used to calculate the specific texture parameters.

\subsubsection{Sensory Analysis}

The sensory evaluation of the biscuits took place in the Laboratory for Sensory Analysis from the authors' faculty, under normal daylight conditions. All samples were evaluated for acceptability using a nine-point hedonic scale. A total number of 52 evaluators (40 females and 12 males) between 19-52 years old participated at the study. The evaluators were students and staff members from the Faculty of Food Science and Technology, selected on basis of their interest, availability and regular consumption of biscuits (at least once per week). Samples were coded anonymously with a three digit code and presented on plastic odour-free plates, in random order. Two replications of each sample were evaluated by each participant. Plain mineral water was provided to clean the palate between samples. Five sensory characteristics were rated on the nine-point hedonic scale: "appearance" ( 1 = extremely irregular surface, 9 = extremely regular surface), "hardness" and "crispiness" ( 1 = extremely weak, 9 = extremely strong), "chewiness" ( 1 = extremely difficult to chew, 9 = extremely easy to chew $)$ and finally, "taste and aroma" $(1=$ no flaxseed taste and aroma, 9 = extremely strong flaxseed taste and aroma). The attributes of hardness were explained to the evaluators and their definitions were also inserted in the evaluation forms. The evaluators were trained with the scale and the sensory attributes used for the evaluation of biscuit samples ( 2 sessions $\times 2 \mathrm{~h}$ ). As already published by Park et al. [49] the hardness was considered the force needed to bite through the sample by using the front teeth. Crispiness was evaluated as the force and the noise with which the sample breaks down between the molar teeth. Finally, the chewiness was evaluated as the energy necessary to masticate solid foods so that they can be easily swallowed.

\subsubsection{Statistical Analysis}

The results of three independent $(n=3)$ replicates were expressed as means \pm standard deviations (SD). Data of proximate composition, sensory data and instrumental textural analysis were analyzed using Duncan multiple comparison test $(p<0.05)$ using the SPSS 
version 19 software (IBM Corp., Armonk, NY, USA). Correlation among means of the sensory data was determined using a two-tailed Pearson Correlation test $(p<0.05)$ using Microsoft Office-Excel.

\section{Results and Discussions}

\subsection{Proximate Composition of Flours}

The proximate composition of WF and RFSF is reported in Table 2. The data show that the two flours have complementary nutritional profiles. The moisture content of any flour is an important quality criterion for its preservation, packaging and transport as well. WF had eight times more humidity than RFSF (14.55\% compared to $1.64 \%$, respectively). The low moisture content for RFSF can be explained by the prior roasting process which removed most of the sample's water content. Comparison of the carbohydrate content of the two samples presented a similar pattern: WF presented high levels of carbohydrates $(74.45 \%)$, whereas RFSF contained $21.76 \%$ of total carbohydrate. However, RFSF presented higher levels of protein $(21.40 \%)$, fiber $(8.75 \%)$ and fat content $(42.50 \%)$ compared to WF.

Table 2. Proximate composition of raw materials.

\begin{tabular}{ccc}
\hline Parameters & Wheat Flour Type 000 (WF) * & Roasted Flaxseed Flour (RFSF) $^{*}$ \\
\hline Moisture $(\%, \mathrm{fw})$ & $14.55 \pm 1.20^{\mathrm{b}}$ & $1.64 \pm 0.04^{\mathrm{a}}$ \\
Protein $(\%, \mathrm{fw})$ & $9.12 \pm 1.03^{\mathrm{a}}$ & $21.40 \pm 1.50^{\mathrm{b}}$ \\
Ash $(\%, \mathrm{fw})$ & $0.48 \pm 0.01^{\mathrm{a}}$ & $3.95 \pm 0.04^{\mathrm{b}}$ \\
Fat $(\%, \mathrm{fw})$ & $1.03 \pm 0.20^{\mathrm{a}}$ & $42.50 \pm 1.50^{\mathrm{b}}$ \\
Crude fiber $(\%, \mathrm{fw})$ & $0.37 \pm 0.23^{\mathrm{a}}$ & $8.75 \pm 1.45^{\mathrm{b}}$ \\
Total carbohydrate $(\%, \mathrm{fw})$ & $74.45 \pm 0.9^{\mathrm{b}}$ & $21.76 \pm 0.76^{\mathrm{a}}$ \\
\hline
\end{tabular}

*Values represent mean of three independent determinations \pm SD; Mean values followed by the same superscript alphabet in the row are not significantly different at $p<0.05$ according to Duncan comparison test; fw-fresh weight.

Therefore, a composite flour can be successfully used to obtain biscuits with improved nutritional value. These results are in agreement with those obtained by Kaur et al. [26] and Kelapure [50] who found the fat content of flaxseed flour was 38.2 and $40.5 \%$. The protein, crude fiber, and ash content of RFSF, in our study, was observed to be $21.40 \%$, $8.75 \%$, and $3.95 \%$, respectively. These values correlated well with the values reported earlier by Hussain et al. [19], Kaur et al. [26], Masoodi [29] and Kelapure [50].

The valuable chemical composition of RFSF along with the high carbohydrate content of WF, especially starch, led to a composite flour with good characteristics for biscuit manufacturing. Mamat and Hill [51] showed that flour with high carbohydrate content and low in gluten is highly recommended for biscuit manufacturing. Therefore, we considered that the composite flours with $25 \%$ RFSF could be successfully used for further processing. WF contributes to the final characteristics of biscuits with the pasting properties of the starch and with the gluten content. Moreover, the high protein content of RFSF could contribute also to the pasting property on the finished product and to the dough viscosity, as it was reported previously in the development of protein-enriched composite flour for biscuits production [52].

\subsection{Volatile Compounds of Raw and Roasted Flaxseed}

The purpose of the analysis was to compare the volatile compounds profile of both raw and roasted flaxseed, to explain, based on the identified volatile compounds, consumers' acceptability of roasted seeds. As a result, a total number of 18 aroma compounds were identified by using ITEX/GS-MS and are presented in Table 3 group in six classes of compounds: alcohols, aldehydes, ketones, terpenes, and terpenoids, acids and others. 
Table 3. Volatile compounds of raw flaxseeds and roasted flaxseed.

\begin{tabular}{|c|c|c|c|c|}
\hline Volatile Compounds & RT (Retention Time, min) & Raw Flaxseeds (\%) * & Roasted Flaxseed (\%) * & Aroma Characteristics ** \\
\hline \multicolumn{5}{|c|}{ Alcohols } \\
\hline 3-Methylbutan-1-ol & 3.904 & $2.75 \pm 0.05^{\mathrm{a}}$ & $4.48 \pm 0.03^{\mathrm{b}}$ & Whiskey, malt, burnt \\
\hline 2-Methylbutan-1-ol & 3.983 & $3.81 \pm 0.21^{\mathrm{a}}$ & $3.64 \pm 0.0322^{a}$ & Malt \\
\hline Pentan-1-ol & 4.843 & $3.97 \pm 0.11^{\mathrm{b}}$ & $1.38 \pm 0.21^{\mathrm{a}}$ & Fruit, balsamic \\
\hline Hexan-1-ol & 9.943 & $23.06 \pm 0.03^{b}$ & $3.74 \pm 0.11^{\mathrm{a}}$ & Resin, flower, green \\
\hline Phenol & 15.682 & $3.63 \pm 0.03^{a}$ & $2.99 \pm 0.61^{\mathrm{a}}$ & Whiskey, malt, burnt \\
\hline \multicolumn{5}{|c|}{ Aldehydes } \\
\hline Hexanal & 6.059 & N.D. & $24.24 \pm 0.21$ & $\begin{array}{l}\text { Grass, tallow, fat, } \\
\text { fruity, sweaty }\end{array}$ \\
\hline Benzaldehyde & 14.758 & $5.76 \pm 0.11^{\mathrm{a}}$ & $10.42 \pm 0.32^{b}$ & Almond, burnt sugar \\
\hline Nonanal & 19.753 & $1.55 \pm 0.08^{\mathrm{a}}$ & $2.85 \pm 0.11^{\mathrm{b}}$ & Fat, citrus, green \\
\hline Decanal & 22.41 & $1.82 \pm 0.03^{\mathrm{a}}$ & $1.25 \pm 0.04^{\mathrm{a}}$ & Orange peel, tallow \\
\hline \multicolumn{5}{|c|}{ Ketones } \\
\hline Acetophenone & 18.532 & $13.22 \pm 0.21^{\mathrm{a}}$ & $17.28 \pm 0.21^{\mathrm{b}}$ & Must, flower, almond \\
\hline Benzophenone & 31.22 & $3.18 \pm 0.03^{b}$ & $1.85 \pm 0.11^{\mathrm{a}}$ & Balsamic \\
\hline \multicolumn{5}{|c|}{ Terpenes and terpenoids } \\
\hline$\alpha$-Pinene & 13.358 & $12.70 \pm 0.21^{\mathrm{b}}$ & $6.81 \pm 0.30^{\mathrm{a}}$ & Pine \\
\hline$\beta$-Pinene & 15.343 & $4.80 \pm 0.21^{b}$ & $1.99 \pm 0.03^{\mathrm{a}}$ & Pine, resin \\
\hline D-limonene & 17.32 & $10.72 \pm 0.10^{b}$ & $9.85 \pm 0.03^{a}$ & Citrus, mint \\
\hline Camphene & 14.117 & $2.48 \pm 0.21$ & N.D. & Camphor \\
\hline \multicolumn{5}{|c|}{ Acids } \\
\hline Benzoic acid & 21.15 & $1.19 \pm 0.21$ & N.D. & Balsamic \\
\hline \multicolumn{5}{|c|}{ Others } \\
\hline 2-Methyloctane & 9.503 & $4.51 \pm 0.02^{b}$ & $2.80 \pm 0.02^{a}$ & Alkane \\
\hline 2-Pentylfuran & 15.97 & N.D. & 2.95 & Fruity \\
\hline
\end{tabular}

* Each value was the mean of triplicate measurements; N.D.- - not detected. ** drawn from [46,47]; Note: ${ }^{\mathrm{a}, \mathrm{b}}$ different superscripts in a row indicate significant differences within samples $(p<0.05)$ according to Duncan comparison test.

It was found that the main volatile compounds of raw flaxseed were hexan-1-ol (23.06\%), acetophenone (13.22\%), $\alpha$-pinene $(12.70 \%)$, D-limonene $(10.72 \%)$ and on the other hand, the major volatile compounds in the roasted flaxseed were hexanal $(24.24 \%)$, acetophenone (17.28\%), benzahdehyde (10.42\%), D-limonene $(9.85 \%), \alpha$-pinene $(6.81 \%)$, 3-methylbutan-1-ol (4.48\%) and hexan-1-ol (3.74\%), respectively (Table 3).

Compounds with fresh and balsamic aroma characteristics, for example hexan-1ol, benzophenone, $\beta$-pinene, D-limonene, camphene and benzoic acid, were present in significantly higher $(p<0.05)$ amounts in raw flaxseed compared to roasted flaxseed. With respect to hexan-1-ol, a lipid oxidation volatile compound with a significant value in raw flaxseed, its amount could be justified by the activity of dehydrogenase enzyme during storage [53].

In the roasted flaxseed compounds with aromas like malt, burned sugar and almond were found in significantly higher amounts $(p<0.05)$ than in raw flaxseed. Hexanal is the primary oxidation product of linoleic acid [52]. The increase of hexanal in roasted flaxseed reaching a final value of $24.24 \%$ may be due to lipid oxidation during thermal treatment [54]. Roasted flaxseeds are a rich source of lipids and in the present study, a total amount of $42.50 \%$ total fat was previously mentioned. Furthermore, Wei et al. [53] reported a higher content of $\alpha$-linolenic acid, the precursor of docosahexaenoic and eicosapentaenoic acids, in flaxseeds, thus explaining the formation of hexanal during the roasting process. Furthermore, acetotophenone (17.28\%) was the major volatile compound from the ketone group, while the main alcohol identified was 3-methylbutan-1-ol (4.48\%). The presence of aldehydes, ketones and alcohols in the roasted flaxseeds could be justified by thermal reactions during roasting such as non-enzymatic Maillard reactions and sugar caramelization. Likewise, the aforementioned compounds could also be formed as a result of lipid oxidation [54]. 


\subsection{Proximate Composition for Biscuits with RFSF}

The proximate composition of the biscuits with RFSF (B0, B10, B25, B40) is summarized in Table 4 Incorporation of the RFSF in biscuits has a significant influence on the major components $(p<0.05)$ and a decrease of the moisture content was observed while fat, ash, protein and fiber content of composite flour mixes increased. RFSF had a significant $(p<0.05)$ effect on the moisture content of the biscuits compared to the control with a decrease in moisture content from $7.34 \%$ to $4.92 \%$. Similar patterns were previously noticed by Khouryieh and Aramouni [55] and Kaur et al. [26] who found that as the flaxseed flour concentration increased in the blend, the moisture content of cookies decreased. These results may be due to low moisture content $(1.64 \%)$ of RFSF. Moreover, a high amount of fat $(42.50 \%)$ was recorded in RFSF, which also contributed to the hydration of the dough, thus reducing the moisture of the biscuits. Furthermore, the low moisture content of the biscuits allows a longer preservation period, due to minimal microbial or chemical activity.

Table 4. Proximate characteristics of the biscuits samples.

\begin{tabular}{|c|c|c|c|c|}
\hline \multirow{2}{*}{ Parameters } & \multicolumn{4}{|c|}{ Biscuit Samples * } \\
\hline & B0 & B10 & B25 & B40 \\
\hline \multicolumn{5}{|c|}{ Proximate Composition ( $\%$ fw) } \\
\hline Moisture (\%) & $7.34 \pm 0.10^{\mathrm{d}}$ & $6.50 \pm 0.20^{c}$ & $5.7 \pm 0.15^{b}$ & $4.92 \pm 0.14^{\mathrm{a}}$ \\
\hline Protein $(\%)$ & $8.35 \pm 0.50^{\mathrm{a}}$ & $9.12 \pm 0.20^{b}$ & $9.89 \pm 0.40^{\mathrm{c}}$ & $10.77 \pm 0.90^{\mathrm{d}}$ \\
\hline Ash (\%) & $1.23 \pm 0.02^{\mathrm{a}}$ & $1.61 \pm 0.05^{\mathrm{b}}$ & $2.13 \pm 0.07^{c}$ & $2.60 \pm 0.02^{\mathrm{d}}$ \\
\hline Fat $(\%)$ & $15.19 \pm 0.90^{\mathrm{a}}$ & $19.06 \pm 1.01^{b}$ & $23.88 \pm 1.20^{\mathrm{c}}$ & $28.34 \pm 1.50^{\mathrm{d}}$ \\
\hline Crude fiber (\%) & $0.75 \pm 0.92^{\mathrm{a}}$ & $1.95 \pm 0.04^{\mathrm{b}}$ & $3.20 \pm 0.14^{c}$ & $5.05 \pm 0.45^{\mathrm{d}}$ \\
\hline Total carbohydrate (\%) & $67.14 \pm 0.70^{\mathrm{d}}$ & $61.76 \pm 0.06^{\mathrm{c}}$ & $55.19 \pm 0.21^{b}$ & $48.32 \pm 0.32^{\mathrm{a}}$ \\
\hline TPC (mg GAE/100 g, fw) & $63.06 \pm 0.07^{\mathrm{a}}$ & $69.95 \pm 0.03^{b}$ & $74.23 \pm 0.12^{c}$ & $78.82 \pm 0.26^{\mathrm{d}}$ \\
\hline DPPH (\%RSA) & $13.57 \pm 0.14^{\mathrm{a}}$ & $18.89 \pm 0.09^{b}$ & $26.41 \pm 0.29^{c}$ & $32.03 \pm 0.71^{\mathrm{d}}$ \\
\hline
\end{tabular}

* Values represent mean of three independent determinations \pm SD; fw-fresh weight; Mean values followed by the same superscript alphabet in the row are not significantly different at $p<0.05$ according to Duncan comparison test.

Ash content increased from $1.23 \%$ (control biscuits) to $2.60 \%$ (sample B40). This might be due to the higher mineral content of flaxseed flour [56,57]. Also, the protein content increased significantly $(p<0.05)$ from $8.35 \mathrm{~g} / 100 \mathrm{~g}$ in B0 to $10.77 \mathrm{~g} / 100 \mathrm{~g}$ in B40 and fat from $15.19 \mathrm{~g} / 100 \mathrm{~g}$ in B0 to $28.34 \mathrm{~g} / 100 \mathrm{~g}$ in B40. Moreover, the addition of $40 \%$ RFSF registered a positive influence on the fibre content of the final baked biscuits, increasing its value about 6.7-fold compared to the control sample. Improving the nutritional value of pastry products by substituting wheat flour with other fiber-rich sources was also recommended by others [58,59]. This increase could be explained by the fact that roasted flaxseed flour is far higher in fat, protein and crude fiber content compared with wheat flour as mentioned in the proximate analysis section of this article.

The total carbohydrate content was significantly decreased $(p<0.05)$ in biscuits substituted with flaxseed from $61.76 \%$ to $48.32 \%$ compared to control biscuits $(67.14 \%)$. These results are similar with the results obtained by Ahmed et al. [60] El-Demery et al. [61] mentioned that as the level of substitution with flaxseed flour increased, all compounds increased except total carbohydrate. Other authors also revealed that the substitution of wheat flour with flaxseed flour resulted in a considerable improvement in protein, crude fiber and ash of biscuit samples [12,16,24,26,50,59,62].

TPC and DPPH of biscuit samples increased with the substitution level of RFSF to WF in the blends. The highest increase in DPPH activity and TPC was exhibited by sample B40 (32.03\% RSA and $78.82 \mathrm{mg}$ GAE/100 g) and the lowest (13.67\% RSA and $63.06 \mathrm{mg}$ GAE/100 g) was shown by the control sample. Similar results have been obtained by Kaur, et al. [26,33]. This increase can be explained by the fact that flaxseed possesses a very powerful antioxidant system, being particularly rich in lignans, e.g., secoisolariciresinol diglucoside (SDG), which are also present in flaxseed oil. [63]. Besides 
lignans, flaxseed contains high amounts of phenolic compounds, such as ferulic acid, syringic acid, cinnamic acid, vanillic acid, $p$-coumaric acid and gallic acid [64]. However, although flaxseed enriches the material basis for exerting its antioxidant activity, previous studies have observed differences in the quality characteristics of flaxseed varieties from different regions of the world, indicating some geographical and varietal specificity [64]. Deng et al. [64] reported that the total phenolic contents in studied flaxseed varieties ranged from $109.93 \mathrm{mg} \mathrm{GAE} / 100 \mathrm{~g}$ to $246.88 \mathrm{mg} \mathrm{GAE} / 100 \mathrm{~g}$, and the DPPH values ranged from $32.56 \mathrm{mg} \mathrm{TE} / 100 \mathrm{~g}$ to $46.22 \mathrm{mg} \mathrm{TE} / 100 \mathrm{~g}$. Even if the roasting process of flaxseeds could produce a slight decrease in the antioxidant activity, the baking process resulted in a significant increase in antioxidative activity due to the Maillard pigments recognized as having a high antioxidative capacity [59].

\subsection{Mineral Content of Biscuits}

The results of the evaluation of the mineral content of biscuits are displayed in Table 5 . The addition of RFSF increased the $\mathrm{P}, \mathrm{K}, \mathrm{Zn}, \mathrm{Fe}, \mathrm{Ca}$ and $\mathrm{Mg}$ contents, meanwhile $\mathrm{Cu}$ and Mn could not be identified in the biscuit samples.

Table 5. The concentration of macro and microelements in biscuit samples.

\begin{tabular}{ccccc}
\hline \multirow{2}{*}{$\begin{array}{c}\text { Mineral Content } \\
(\mathbf{m g} / \mathbf{1 0 0} \mathbf{g}, \mathbf{f w})\end{array}$} & $\mathbf{4}$ & \multicolumn{4}{c}{ Biscuit Samples * $^{*}$} & $\mathbf{B}$ & $\mathbf{B 1 0}$ & $\mathbf{B 2 5}$ & $\mathbf{B} 40$ \\
\cline { 2 - 5 } & $27.83 \pm 0.03^{\mathrm{a}}$ & $35.64 \pm 0.39^{\mathrm{b}}$ & $43.20 \pm 067^{\mathrm{c}}$ & $49.78 \pm 0.03^{\mathrm{d}}$ \\
$\mathrm{P}$ & $240.46 \pm 0.89^{\mathrm{a}}$ & $275.38 \pm 0.76^{\mathrm{b}}$ & $313.08 \pm 0.55^{\mathrm{c}}$ & $356.99 \pm 0.99^{\mathrm{d}}$ \\
$\mathrm{Cu}$ & N.D. & N.D. & N.D. & N.D. \\
$\mathrm{Zn}$ & $0.71 \pm 0.09^{\mathrm{a}}$ & $1.12 \pm 0.03^{\mathrm{b}}$ & $1.54 \pm 0.05^{\mathrm{c}}$ & $1.97 \pm 0.02^{\mathrm{d}}$ \\
$\mathrm{Fe}$ & $1.40 \pm 0.03^{\mathrm{a}}$ & $1.87 \pm 0.05^{\mathrm{b}}$ & $2.27 \pm 0.07^{\mathrm{c}}$ & $2.76 \pm 0.11^{\mathrm{d}}$ \\
$\mathrm{Mn}$ & N.D. & N.D. & N.D. & N.D. \\
$\mathrm{Ca}$ & $164.46 \pm 0.83^{\mathrm{a}}$ & $195.43 \pm 0.79^{\mathrm{b}}$ & $223.05 \pm 0.85^{\mathrm{c}}$ & $256.09 \pm 0.533^{\mathrm{d}}$ \\
$\mathrm{Mg}$ & $41.36 \pm 0.55^{\mathrm{a}}$ & $90.16 \pm 0.59^{\mathrm{b}}$ & $141.47 \pm 0.88^{\mathrm{c}}$ & $191.33 \pm 0.39^{\mathrm{d}}$ \\
\hline
\end{tabular}

*Values represent mean of three independent determinations \pm SD; fw-fresh weight; Mean values followed by the same superscript alphabet in the row are not significantly different at $p<0.05$ according to Duncan comparison test. N.D.-not determined.

The significant increase of minerals $(p<0.05)$ in biscuits could be justified by the rich minerals content of RFSF. A large body of literature highlighted that flaxseeds are a valuable source of minerals. For instance, Bernacchia et al. [65] showed that $\mathrm{P}, \mathrm{K}, \mathrm{Ca}, \mathrm{Mg}$ flaxseed content reached values of 622, 831, 236 and $431 \mathrm{mg} / 100$ g, respectively. Furthermore, Kaur et al. [57] mentioned that flaxseed is rich in $\mathrm{Mg}$ which is the second most abundant element in human body, as well as in $\mathrm{K}$, which is the most common macro-mineral with positive effect in reduction of stroke incidence and blood platelets aggregation.

It is important to note that mineral content could vary between flaxseed cultivars and could be influenced by external factors such as soil conditions, fertilizers, water availability, climatic conditions and genetic factors [57].

\subsection{Analysis of Volatile Compounds of Biscuit Samples}

A total number of 21 volatile compounds were identified in the RFSF enriched biscuits, by means of ITEX/GC-MS technique as shown in Table 6. In all biscuit samples, the main volatile compound from the aldehydes group was hexanal, ranging from $14.76 \%$ to $18.39 \%$, meanwhile $\beta$-myrcene and D-limonene were the main volatile compounds from terpenes and terpenoids group, ranging from $8.99 \%$ to $15.65 \%$ and $2.47 \%$ to $8.48 \%$, respectively. Acetophenone was the major volatile compound from the ketones group with values between $2.50 \%$ to $10.98 \%$, meanwhile, 4 -methyloctane reached a final value of $6.92 \%$ in the B40 sample. The presence of 4-methyloctane could be justified by the addition of vanilla essence during the biscuit manufacturing [66]. The amount of D-limonene in RFSF increased linearly with increasing levels of RFSF in the final baked products. D-Limonene is responsible for odour perceptions like citrus and mint. Furthermore, flaxseed represent 
a high source of carotenoids [67] which could be correlated with higher amounts of Dlimonene, as reported by Chiş et al. [68]. From the terpenes and terpenoids group apart from D-limonene, $\beta$-myrcene enhanced the final odour perception through its balsamic, musty and spice perceptions.

Table 6. Volatile compounds content of the biscuits with roasted flaxseed flour.

\begin{tabular}{|c|c|c|c|c|c|c|}
\hline \multirow{2}{*}{ Volatile Compounds } & \multirow{2}{*}{$\begin{array}{l}\text { RT (Retention } \\
\text { Time, min) }\end{array}$} & \multicolumn{4}{|c|}{ Biscuit Samples * } & \multirow{2}{*}{ Aroma Characteristics ** } \\
\hline & & B0 & B10 & B25 & B40 & \\
\hline \multicolumn{7}{|c|}{ Alcohols } \\
\hline Phenol & 15.65 & $1.83 \pm 0.03^{b}$ & $1.8 \pm 0.02^{b}$ & $1.13 \pm 0.03^{\mathrm{a}}$ & $3.63 \pm 0.04^{c}$ & Phenol \\
\hline \multicolumn{7}{|c|}{ Aldehydes } \\
\hline Hexanal & 6.07 & $18.39 \pm 0.05^{c}$ & $14.76 \pm 0.12^{\mathrm{a}}$ & $15.35 \pm 0.22^{a}$ & $16.36 \pm 0.03^{b}$ & Grass, tallow, fat \\
\hline Heptanal & 11.926 & $0.63 \pm 0.02^{b}$ & $0.19 \pm 0.02^{\mathrm{a}}$ & $0.98 \pm 0.04^{c}$ & $1.12 \pm 0.07^{c}$ & Fat, citrus \\
\hline Octanal & 16.506 & $0.97 \pm 0.03^{\mathrm{a}}$ & $0.87 \pm 0.06^{\mathrm{a}}$ & $1.20 \pm 0.05^{\mathrm{b}}$ & $1.46 \pm 0.04^{c}$ & Lemon, green \\
\hline Nonanal & 19.74 & $5.13 \pm 0.22^{c}$ & $3.12 \pm 0.11^{b}$ & $1.69 \pm 0.05^{\mathrm{a}}$ & $2.99 \pm 0.03^{b}$ & Fat, citrus, green \\
\hline Benzaldehyde & 14.744 & $2.40 \pm 0.03^{\mathrm{a}}$ & $5.08 \pm 0.21^{b}$ & $7.18 \pm 0.33^{c}$ & $8.82 \pm 0.03^{c}$ & Almond, burnt sugar \\
\hline Decanal & 22.412 & $0.59 \pm 0.04^{\mathrm{b}}$ & $0.45 \pm 0.02^{\mathrm{a}}$ & $0.62 \pm 0.03^{b}$ & $0.90 \pm 0.02^{c}$ & Orange peel, tallow \\
\hline \multicolumn{7}{|c|}{ Ketones } \\
\hline Heptan-2-one & 11.167 & $0.89 \pm 0.04^{\mathrm{a}}$ & $1.13 \pm 0.02^{\mathrm{a}}$ & $3.82 \pm 0.06^{\mathrm{b}}$ & $4.22 \pm 0.08^{b}$ & $\begin{array}{l}\text { Cheese, fruity, ketonic, } \\
\text { green banana, with a } \\
\text { creamy nuance }\end{array}$ \\
\hline Acetophenone & 18.524 & $2.50 \pm 0.03^{\mathrm{a}}$ & $5.02 \pm 0.02^{b}$ & $8.69 \pm 0.06^{c}$ & $10.98 \pm 0.02^{d}$ & Must, flower, almond \\
\hline Nonan-2-one & 19.341 & $1.59 \pm 0.02^{b}$ & $1.44 \pm 0.03^{\mathrm{b}}$ & $0.53 \pm 0.05^{\mathrm{a}}$ & $1.70 \pm 0.04^{\mathrm{b}}$ & $\begin{array}{l}\text { Fruity, sweet, waxy, } \\
\text { green herbaceous }\end{array}$ \\
\hline Benzophenone & 31.223 & $1.26 \pm 0.04^{\mathrm{c}}$ & $0.72 \pm 0.06^{\mathrm{b}}$ & $0.91 \pm 0.03^{b}$ & $0.44 \pm 0.05^{\mathrm{a}}$ & Balsamic \\
\hline \multicolumn{7}{|c|}{ Terpenes and terpenoids } \\
\hline$\beta$-Myrcene & 15.951 & $8.99 \pm 0.17^{\mathrm{a}}$ & $10.77 \pm 0.23^{a}$ & $12.79 \pm 0.31^{b}$ & $15.65 \pm 0.22^{c}$ & Balsamic, must, spice \\
\hline D-Limonene & 17.323 & $2.47 \pm 0.03^{\mathrm{a}}$ & $4.28 \pm 0.04^{b}$ & $6.14 \pm 0.07^{c}$ & $8.48 \pm 0.03^{\mathrm{d}}$ & Citrus, mint \\
\hline \multicolumn{7}{|c|}{ Acids } \\
\hline Benzoic acid & 21.232 & $9.62 \pm 0.02^{c}$ & $5.91 \pm 0.03^{\mathrm{b}}$ & $7.15 \pm 0.07^{\mathrm{b}}$ & $3.02 \pm 0.03^{\mathrm{a}}$ & Balsamic \\
\hline Dodecanoic acid & 29.711 & $2.47 \pm 0.03^{\mathrm{a}}$ & $4.28 \pm 0.04^{b}$ & $6.14 \pm 0.07^{c}$ & $8.48 \pm 0.03^{\mathrm{d}}$ & Mild fatty, coconut bay oil \\
\hline \multicolumn{7}{|c|}{ Others } \\
\hline Dimethyl disulfide & 4.067 & $7.29 \pm 0.05^{b}$ & $6.67 \pm 0.03^{b}$ & $4.06 \pm 0.12^{\mathrm{a}}$ & $4.27 \pm 0.34^{\mathrm{a}}$ & Sulfurous \\
\hline 2,4-Dimethylheptane & 7.008 & $8.18 \pm 0.22^{c}$ & $6.86 \pm 0.31^{b}$ & $6.81 \pm 0.02^{\mathrm{b}}$ & $3.16 \pm 0.12^{\mathrm{a}}$ & Alkane \\
\hline 4-Methyloctane & 9.388 & $6.55 \pm 0.12^{b}$ & $6.05 \pm 0.05^{\mathrm{a}}$ & $6.75 \pm 0.03^{b c}$ & $6.92 \pm 0.02^{c}$ & Alkane \\
\hline 3,7-Dimethyldecane & 18.213 & $8.79 \pm 0.15^{b}$ & $14.51 \pm 0.21^{c}$ & $5.27 \pm 0.23^{a}$ & $2.95 \pm 0.08^{a}$ & Alkane \\
\hline 3,4-Dimethylundecane & 18.388 & $2.60 \pm 0.07^{b}$ & $2.52 \pm 0.09^{b}$ & $1.20 \pm 0.02^{\mathrm{a}}$ & $0.68 \pm 0.03^{a}$ & Alkane \\
\hline Ethyl 2,4-dioxohexanoate & 16.369 & $0.94 \pm 0.04^{\mathrm{a}}$ & $1.20 \pm 0.03^{\mathrm{ab}}$ & $1.66 \pm 0.05^{b}$ & N.D. & Apple peel, fruit \\
\hline
\end{tabular}

* Each value was the mean of triplicate measurements; N.D.- not detected. ${ }^{* *}$ drawn from $[46,47]$. Note: ${ }^{\text {a-d }}$ different superscripts in a row indicate significant difference within samples $(p<0.05)$ according to Duncan comparison test.

Acetophenone, from the ketone group, was previously pinpointed as a volatile compound with implication in the overall flavor of flour products which could be formed during Maillard reactions [69]. Its odour perception is pleasant, having musty, flowery and almond characteristics.

The increased amount of heptan-2-one from the ketone group with increasing yield of RFSF could be explained by the chemical composition of flaxseed, rich in tocopherol and ascorbic acid [65]. In this line, Starowicz et al. [70] showed that tocopherol and ascorbic acid significantly increased the peak area of heptan-2-one.

Furthermore, a recent study of Hidalgo and Zamora [71] highlighted that benzaldehyde could be formed through chemical reactions such as lipid oxidation. The reaction involved in the first step is a carbonyl-amine reaction followed by a free radical amino-acid degradation, mainly phenylalanine. It was previously shown that flaxseed is a rich source of 6 essential amino-acids, from which phenylalanine amount could vary in the range from $1.44 \mathrm{mg} / 100 \mathrm{~g}$ up to $66.6 \mathrm{mg} / 100 \mathrm{~g}$, depending on the flaxseed cultivars [57]. Therefore, the 
significant differences $(p<0.05)$ between benzaldehyde sample amounts, could be justified by the chemical composition of flaxseed and by lipid oxidation.

It is worth nothing that non-enzymatic Maillard reactions such as the Strecker degradation process could lead to the formation of aldehydes as a result of the reaction of aminoacids with dehydroreductones [54].

Overall, the increased RFSF percentages during biscuits manufacturing, led to significant differences $(p<0.05)$ between aroma volatile compounds, mainly due to the rich chemical composition in lipids, protein, aminoacids, phenols and chemical reactions such as Maillard and lipid oxidation.

\subsection{Physical Characteristics of the Biscuits}

The evaluation results of the physical characteristics of the biscuits indicate that there was a significant difference $(p<0.05)$ between the control sample and B40 in thickness, diameter and spread factor (Table 7). However, there was no significant difference in the weight of any type of biscuit although it was lower than the control biscuits.

Table 7. Physical characteristics of biscuits.

\begin{tabular}{ccccc}
\hline \multirow{2}{*}{ Biscuits Samples } & \multicolumn{4}{c}{ Physical Parameters * } \\
\cline { 2 - 5 } & Weight $\mathbf{( g )}$ & Thickness $\mathbf{( c m )}$ & Diameter $\mathbf{( c m})$ & Spread Factor \\
\hline B0 & $12.9 \pm 1.09^{\mathrm{a}}$ & $0.75 \pm 0.30^{\mathrm{a}}$ & $5.93 \pm 1.20^{\mathrm{a}}$ & $7.90 \pm 1.90^{\mathrm{c}}$ \\
B10 & $12.8 \pm 1.10^{\mathrm{a}}$ & $0.79 \pm 1.00^{\mathrm{ab}}$ & $6.08 \pm 1.04^{\mathrm{b}}$ & $7.70 \pm 1.50^{\mathrm{bc}}$ \\
B25 & $12.7 \pm 1.40^{\mathrm{a}}$ & $0.83 \pm 0.50^{\mathrm{b}}$ & $6.17 \pm 1.09^{\mathrm{bc}}$ & $7.43 \pm 2.10^{\mathrm{b}}$ \\
B40 & $12.6 \pm 1.25^{\mathrm{a}}$ & $0.89 \pm 0.90^{\mathrm{c}}$ & $6.26 \pm 1.30^{\mathrm{c}}$ & $7.03 \pm 2.90^{\mathrm{a}}$ \\
\hline
\end{tabular}

* Values represent mean of three independent determinations \pm SD. Mean values followed by the same superscript alphabet in the column are not significantly different at $p<0.05$ according to Duncan comparison test.

The diameter and thickness of biscuit samples (B10, B25 and B40) increased slightly with increasing substitution percentage of RFSF compared with control biscuit (B0). Sample B40 presented the maximum diameter and thickness $(6.26$ and $0.89 \mathrm{~cm})$. The spread factor is the ratio that depends on the values of the thickness and diameter of the cookies and it is used to determine the quality of flour for producing cookies [26]. The results of the spread ratio of biscuits revealed a significant reduction $(p<0.05)$ in spread ratio from 7.90 to $7.03 \mathrm{~cm}$ for B40. With the increase in the concentration of RFSF, the spread factor of biscuits gradually decreased. These results are in the line with the findings of other authors $[16,32]$ who stated that proteins and dietary fibers have more water-binding power. Ganorkar and Jain [16], argue that the presence of more water in the dough, leads to higher dissolution of sugar during mixing and this lowers the initial dough viscosity and the cookie is able to spread at a faster rate during cooking. Moreover, in the opinion of the same authors, an inverse correlation is obtained when the flour components absorb large quantities of water and, as a consequence, reduce the amount of water that is available to dissolve the sugars in the formula. Therefore, the initial viscosity is higher and the biscuits spread less during baking.

\subsection{Instrumental Analysis of Texture}

The results of the instrumental analysis of texture are presented in Table 8. Instrumental analysis of hardness showed statistically significant differences $(p<0.05)$ between control (B0) and B40. Hardness decreased as the amount of RFSF increased, mean values of 10,655 g (control sample) and $5714 \mathrm{~g}$ (B40), respectively. Similar patterns were noticed for the load required to reach the hardness work value. The values of hardness work $(\mathrm{mJ})$ decreased with increasing RFSF from $262.73 \mathrm{~mJ}$ to $122.30 \mathrm{~mJ}$. These results are similar to those obtained by Ganorkar and Jain [16] and Omran et al. [32] who reported that the textural parameters were found to decrease with increasing flaxseed flour incorporation. This might be due to an increase in dietary fiber and protein, high water absorbing capacity components as well as due to the high level of fat $(42.50 \%)$ found in RFSF. These factors 
contributed to a sticky dough which reduced the extensibility of dough. Previous studies claim that with an increase in fat content, the gluten network gets interrupted thus the physical properties of biscuits are changed and become less hard. At very high fat content the lubricating function is high and a soft texture is obtained. Hence the hardness gradually decreases forming softer biscuits with an increased level of flaxseed flour [16,32,72].

Table 8. Instrumental analysis of texture.

\begin{tabular}{ccccc}
\hline Sample & B0 & B10 & B25 & B40 \\
\hline $\begin{array}{c}\text { Hardness cycle 1 (g) } \\
\text { Hardness Work } \\
\text { cycle 1 (mJ) }\end{array}$ & $10,655 \pm 21^{\mathrm{d}}$ & $8801 \pm 80^{\mathrm{c}}$ & $7136 \pm 69^{\mathrm{b}}$ & $5714 \pm 34^{\mathrm{a}}$ \\
\hline
\end{tabular}

Values represent mean of three independent determinations \pm SD. Mean values followed by the same superscript alphabet in the row are not significantly different at $p<0.05$ according to Duncan comparison test.

\subsection{Sensory Analysis}

Before a product becomes commercially available, many tests are conducted with consumers to evaluate the product acceptability. Nowadays, consumers are more health conscious then before and functional foods have an ascending trend on the market. This context brings new challenges upon sensory analysis, transforming it into a more proactive role in producing unique, innovative and functional products. Austria et al. [73] hypothesised that foods that contain significant quantities of flaxseed will be well tolerated by the public.

The mean of hedonic scores and their standard deviation are presented in Table 9. The control sample scored the highest for appearance, hardness, chewiness and aftertaste.

Table 9. Sensory evaluation of the biscuits.

\begin{tabular}{cccccccc}
\hline Sample & Appearance & Hardness & Crispiness & Chewiness & Taste and Aroma & Aftertaste & $\begin{array}{c}\text { Overall } \\
\text { Appreciation }\end{array}$ \\
\hline B0 & $5.83 \pm 1.34^{\mathrm{c}}$ & $3.58 \pm 1.07^{\mathrm{b}}$ & $5.38 \pm 1.48^{\mathrm{a}}$ & $6.15 \pm 1.32^{\mathrm{b}}$ & $5.77 \pm 0.83^{\mathrm{a}}$ & $5.02 \pm 1.79^{\mathrm{c}}$ & $6.88 \pm 1.15^{\mathrm{ab}}$ \\
\hline $\mathrm{B} 10$ & $5.62 \pm 1.39^{\mathrm{c}}$ & $2.37 \pm 0.84^{\mathrm{a}}$ & $6.79 \pm 1.75^{\mathrm{b}}$ & $5.33 \pm 1.46^{\mathrm{a}}$ & $6.10 \pm 0.72^{\mathrm{b}}$ & $4.42 \pm 1.35^{\mathrm{b}}$ & $6.92 \pm 1.20^{\mathrm{ab}}$ \\
\hline B25 & $4.94 \pm 1.38^{\mathrm{b}}$ & $2.88 \pm 0.92^{\mathrm{ab}}$ & $6.56 \pm 1.64^{\mathrm{b}}$ & $5.50 \pm 1.42^{\mathrm{a}}$ & $6.42 \pm 1.05^{\mathrm{c}}$ & $4.23 \pm 1.65^{\mathrm{b}}$ & $6.75 \pm 1.37^{\mathrm{a}}$ \\
\hline B40 & $4.35 \pm 1.69^{\mathrm{a}}$ & $2.65 \pm 1.25^{\mathrm{a}}$ & $7.12 \pm 1.96^{\mathrm{c}}$ & $5.40 \pm 1.65^{\mathrm{a}}$ & $6.87 \pm 1.47^{\mathrm{d}}$ & $3.90 \pm 2.04^{\mathrm{a}}$ & $6.94 \pm 1.49^{\mathrm{b}}$ \\
\hline
\end{tabular}

Values represent hedonic scores calculated as mean $\pm \mathrm{SD}(n=52)$. Mean values followed by the same superscript alphabet in the column are not significantly different at $p<0.05$ according to Duncan comparison test.

For the attribute of appearance no significant difference was encountered between the control sample and the B10. However, all tested samples which contained flaxseed flour (B10, B25 and B40) scored progressively lower than the control (B0). This can be explained by the fact that evaluators were able to visually discriminate the samples solely based on their color and degree of irregularities which could be seen on the surface of the biscuit. The decrease of the hedonic appearance values may be due to the progressive decrease amount of moisture and total carbohydrates in the biscuit samples $(\mathrm{B} 0>\mathrm{B} 10>\mathrm{B} 25>\mathrm{B} 40$ as can be seen in Table 4) which caused the depreciation of biscuits' surface and darker color during baking. There was a positive correlation between appearance and moisture $(0.97, p<0.05)$, and between appearance and total carbohydrates $(0.99, p<0.05)$. Moreover, the appearance negatively correlated with ash $(-0.99, p<0.05)$, fat $(-0.99, p<0.05)$ and crude fiber $(-0.98, p<0.05)$. The decrease of appearance perception with the increase of the flaxseed content was also recorded previously in studies performed on biscuits $[29,32,74]$ as well as on other bakery products, like cookies $[19,75]$ muffins $[76,77]$ and bread [13].

The texture plays a key role in assessing consumers' acceptance of a food product. The complex changes of the texture during the process of eating (mouth behaviour) can influence the acceptance or rejection of the product. Although most of the times it is 
unconscious, the consumer's preference toward a product is often due to the texture. The biscuits were evaluated by three different textural attributes: hardness, crispiness and chewiness. Each attribute was clearly explained to the participants and a brief description of them was inserted in the evaluation sheet next to the hedonic scale as stated in the method section. The participants were instructed to evaluate the crispiness as the force and noise created when the sample breaks during chewing the sample between the molar teeth. It was noted that the biscuits with higher amount of RFSF presented lower amount of moisture (Table 4$)$. Negative correlation $(p<0.05)$ was found between the consumer's perception of crispiness and the amount of moisture and total carbohydrates of the biscuits ( -0.85 and -0.82 , respectively). Similar findings were published by Hussain et al. [19] and Marpalle et al. [13]. This result can be explained by flaxseed's capacity to bind water, which influences the textural properties of the final product [76].

Taste and aroma improved with the increasing amount of the flaxseed in the biscuits. The flaxseed has a unique nutty flavour (Tables 3 and 7) which was found pleasant by the consumers, therefore the taste and aroma characteristics of samples with RFSF scored higher than the control $(\mathrm{B} 0>\mathrm{B} 10>\mathrm{B} 25>\mathrm{B} 40)$. Moreover, the taste and aroma of the samples was positively correlated with the biscuits' content in protein $(0.99, p<0.005)$, ash $(0.99, p<0.005)$, fat $(0.99, p<0.005)$ and crude fiber $(0.99, p<0.001)$ and negatively correlated with moisture $(-0.99, p<0.005)$ and total carbohydrates $(-0.99, p<0.01)$. Some authors mention a bitter taste in samples prepared with high amounts of flaxseed flour [78]. However, in this study, the nutty flavour was appreciated by the consumers which are accustomed to the taste and flavor of different types of traditional biscuits and cookies prepared with various amounts of nuts.

The aftertaste correlated negatively with the biscuit's content in protein $(-0.97$, $p<0.05)$, ash $(-0.95, p<0.05)$, fat $(-0.96, p<0.05)$ and crude fiber $(-0.95, p<0.05)$ and correlated positively with moisture $(0.97, p<0.05)$ and total carbohydrates $(0.96, p<0.05)$.

Although the sensory attributes of the samples with RFSF were decreased compared to the control, the aroma and crispiness increased and the significant differences between samples in appearance, hardness, chewiness and aftertaste did not reflect on the overall appreciation of the biscuits.

\section{Conclusions}

The results of this study reveal the effect of roasted flaxseed flour addition on the physico-chemical parameters, volatile profile, and sensory acceptability of biscuits. The high incorporation of RFSF advantageously influenced the nutritional properties of biscuits as evidenced by significant increases in the fibre contents (about 6.7-fold higher than in control biscuits), proteins and minerals. Furthermore, the addition of RFSF increased the total phenolic content and radical scavenging activity amount, reaching final values for biscuits manufactured with 40\% RFSF such as $78.82 \mathrm{mg} \mathrm{GAE} / 100 \mathrm{~g}$ and $32.03 \%$, respectively. With respect to the volatile profile of biscuits, the addition of RFSF leads to the formation of aroma compounds such as hexanal, $\beta$-myrcene, D-limonene, acetophenone and 4-methyloctane, having odor perceptions such as grass, balsamic, must, citrus mint and alkane. Sensory evaluation indicated that the overall biscuits appreciation was not affected in a significant way $(p<0.05)$ by RFSF addition, meanwhile the aftertaste intensity decreased. Considering the nutritional, textural and sensorial analysis of the final baked goods, we can conclude that $25 \%$ RFSF could be successfully used in biscuit manufacturing.

Author Contributions: Conceptualization, S.M.M. and M.S.C.; methodology, V.M., S.A.S., L.S. and A.P. (Anamaria Pop); software, M.S.C., L.S.; validation, S.A.S. and A.P. (Adriana Păucean); formal analysis, M.S.C., S.A.S., S.M.M. and L.S.; writing—original draft preparation, S.M.M., M.S.C. and L.S.; writing-review and editing, A.P. (Adriana Păucean) and L.S.; supervision, L.S., A.P. (Adriana Păucean) and S.M.M.; project administration, S.M.M., S.M. All authors have read and agreed to the published version of the manuscript.

Funding: This research received no external funding. 
Acknowledgments: This work was supported by a grant of Romanian Ministry of Research and Innovation, CNCS-UEFISCDI, project number PN-III-P4-ID-PCE2020-1847, within PNCDI III.

Conflicts of Interest: The authors declare no conflict of interest.

\section{References}

1. Bala, A.; Gul, K.; Riar, C.S. Functional and sensory properties of cookies prepared from wheat flour supplemented with cassava and water chestnut flours. Cogent Food Agric. 2015, 1, 1019815. [CrossRef]

2. Khan, A.; Saini, C.S. Effect of roasting on physicochemical and functional properties of flaxseed flour. Cogent Eng. $2016,3,1145566$. [CrossRef]

3. Chauhan, A.; Saxena, D.C.; Singh, S. Physical, textural, and sensory characteristics of wheat and amaranth flour blend cookies. Cogent Food Agric. 2016, 2, 1125773. [CrossRef]

4. Man, S.; Păucean, A.; Muste, S.; Chiș, M.S.; Pop, A.; Calian-Ianoş, I.D. Assessment of amaranth flour utilization in cookies production and quality. J. Agroaliment. Process. Technol. 2017, 23, 97-103.

5. Katare, C.; Saxena, S.; Agrawal, S.; Prasad, G. Flax Seed: A potential medicinal food. J. Nutr. Food Sci. 2012, 2, 1000120. [CrossRef]

6. Hussain, S.; Anjum, F.M.; Alamri, M.S.; Mohamed, A.A.; Nadeem, M. Functional flaxseed in baking. Qual. Assur. Saf. Crop. Foods 2013, 5, 375-385. [CrossRef]

7. Chishty, S.; Bissu, M. Health benefits and nutritional value of flaxseed-A Review. Indian J. Appl. Res. 2016, 6, $243-245$.

8. Soni, R.P.; Katoch, M.; Kumar, A.; Verma, P. Flaxseed-Composition and its health benefits. Res. Environ. Life Sci. 2016, 9, 310-316.

9. Kanikowska, D.; Korybalska, K.; Mickiewicz, A.; Rutkowski, R.; Kuchta, A.; Sato, M.; Kreft, E.; Fijałkowski, M.; Gruchała, M.; Jankowski, M.; et al. Flaxseed (Linum usitatissimum L.) supplementation in patients undergoing lipoprotein apheresis for severe hyperlipidemia-A pilot study. Nutrients 2020, 12, 1137. [CrossRef]

10. Singh, K.K.; Mridula, D.; Rehal, J.; Barnwal, P. Flaxseed: A potential source of food, feed and fiber. Crit. Rev. Food Sci. Nutr. 2011, 51, 210-222. [CrossRef] [PubMed]

11. Kajla, P.; Sharma, A.; Sood, D.R. Flaxseed-A potential functional food source. J. Food Sci. Technol. 2015, 52, 1857-1871. [CrossRef] [PubMed]

12. Shekhara, N.R.; Anurag, A.P.; Prakruthi, M.; Mahesh, M.S. Flax Seeds (Linum usitatissimmum): Nutritional composition and health benefits. IP J. Nutr. Metab. Health Sci. 2020, 3, 35-40. [CrossRef]

13. Marpalle, P.; Sonawane, S.K.; Arya, S.S. Effect of flaxseed flour addition on physicochemical and sensory properties of functional bread. LWT Food Sci. Technol. 2014, 58, 614-619. [CrossRef]

14. Mohanan, A.; Nickerson, M.T.; Ghosh, S. Oxidative stability of flaxseed oil: Effect of hydrophilic, hydrophobic and intermediate polarity antioxidants. Food Chem. 2018, 266, 524-533. [CrossRef] [PubMed]

15. Moraes, É.A.; de Souza Dantas, M.I.; de Castro Morais, D.; Oliveira da Silva, C.; Ferreira de Castro, F.A.; Martino, H.S.D.; Ribeiro, S.M.R. Sensory evaluation and nutritional value of cakes prepared with whole flaxseed flour. Ciência Tecnol. Aliment. 2010, 30, 974-979. [CrossRef]

16. Ganorkar, P.M.; Jain, R.K. Effect of flaxseed incorporation on physical, sensorial, textural and chemical attributes of cookies. Int. Food Res. J. 2014, 21, 1515-1521.

17. Parikh, M.; Maddaford, T.G.; Austria, J.A.; Aliani, M.; Netticadan, T.; Pierce, G.N. Dietary Flaxseed as a strategy for improving human health. Nutrients 2019, 11, 1171. [CrossRef] [PubMed]

18. Conforti, F.D.; Davis, S.F. The effect of soya flour and flaxseed as a partial replacement for bread flour in yeast bread. Int. J. Food Sci. Technol. 2006, 41, 95-101. [CrossRef]

19. Hussain, S.; Anjum, F.M.; Butt, M.S.; Khan, M.I.; Asghar, A. Physical and sensoric attributes of flaxseed flour supplemented cookies. Turk. J. Biol. 2006, 30, 87-92.

20. Oomah, B.D.; Der, T.J.; Godfrey, D.V. Thermal characteristics of flaxseed (Linum usitatissimum L.) proteins. Food Chem. 2006, 98 , 733-741. [CrossRef]

21. Tarpila, S.; Aro, A.; Salminen, I.; Tarpila, A.; Kleemola, P.; Akkila, J.; Aldercreutz, H. The effect of flaxseed supplementation in processed foods on serum fatty acids and enterolactone. Eur. J. Clin. Nutr. 2002, 56, 157-165. [CrossRef] [PubMed]

22. Codină, G.G.; Istrate, A.M.; Gontariu, I.; Mironeasa, S. Rheological properties of wheat-flaxseed composite flours assessed by mixolab and their relation to quality features. Foods 2019, 8, 333. [CrossRef]

23. Kasote, D.M. Flaxseed phenolics as natural antioxidants. Int. Food Res. J. 2013, 20, 27-34.

24. Park, J.B.; Velasquez, M.T. Potential effects of lignan-enriched flaxseed powder on bodyweight, visceral fat, lipid profile, and blood pressure in rats. Fitoterapia 2012, 83, 941-946. [CrossRef] [PubMed]

25. Goyal, A.; Sharma, V.; Upadhyay, N.; Gill, S.; Sihag, M. Flax and flaxseed oil: An ancient medicine \& modern functional food. J. Food Sci. Technol. 2014, 51, 1633-1653. [CrossRef] [PubMed]

26. Kaur, M.; Singh, V.; Kaur, R. Effect of partial replacement of wheat flour with varying levels of flaxseed flour on physicochemical, antioxidant and sensory characteristics of cookies. Bioact. Carbohydr. Diet. Fibre 2017, 9, 14-20. [CrossRef]

27. Lowcock, E.C.; Cotterchio, M.; Boucher, B.A. Consumption of flaxseed, a rich source of lignans, is associated with reduced breast cancer risk. Cancer Causes Control 2013, 24, 813-816. [CrossRef]

28. Moure, A.; Sineiro, J.; Domínguez, H.; Parajó, J.C. Functionality of oilseed protein products: A review. Food Res. Int. 2006, 39 , 945-963. [CrossRef] 
29. Masoodi, L.; Bashir, V.A.K. Fortification of Biscuit with Flaxseed: Biscuit production and quality evaluation. IOSR J. Environ. Sci. Toxicol. Food Technol. 2012, 1, 06-09. [CrossRef]

30. De Moura, C.C.; Peter, N.; Schumacker, B.D.O.; Borges, L.R.; Helbig, E. Biscoitos enriquecidos com farelo de linhaça marrom (Linum Usitatissiumun L.): Valor nutritivo e aceitabilidade. Demetra Aliment. Nutr. Saúde 2014, 9, 71-82. [CrossRef]

31. Bartkiene, E.; Jakobsone, I.; Pugajeva, I.; Bartkevics, V.; Zadeike, D.; Juodeikiene, G. Reducing of acrylamide formation in wheat biscuits supplemented with flaxseed and lupine. LWT Food Sci. Technol. 2016, 65, 275-282. [CrossRef]

32. Omran, A.A.; Ibrahim, O.S.; Mohamend, Z.E.-O.M. Quality characteristics of biscuit prepared from wheat and flaxseed Flour. Adv. Food Sci. 2016, 38, 129-138.

33. Kaur, P.; Sharma, P.; Kumar, V.; Panghal, A.; Kaur, J.; Gat, J. Effect of addition of flaxseed flour on phytochemical, physicochemical, nutritional, and textural properties of cookies. J. Saudi Soc. Agric. Sci. 2019, 18, 372-377. [CrossRef]

34. Xu, Y.; Hall, C.A.; Manthey, F.A. Chemical composition, antioxidant and antihyperglycemic activities of the wild lactarius deliciosus from China. Molecules 2019, 24, 1357. [CrossRef] [PubMed]

35. Codina, G.G.; Mironeasa, S.; Todosi-Sanduleac, E. Studies regarding the influence of brown flaxseed flour addition in wheat flour of a very good quality for bread making on bread quality. Bull. Univ. Agric. Sci. Vet. Med. Cluj-Napoca Food Sci. Technol. 2016, 73, 70-76. [CrossRef]

36. Silva, L.M.; Gama de Mendonça, L.; Zambelli, R.A.; Magalhães, A.L.M.; Silva da Costa, C.; Venânces de Souza Leão, L.M.; de Albuquerque Ribeiro de Sá Costa, R. Impact of green pulp banana and flaxseed flour on pound cake quality. Int. J. Nutr. Food Sci. 2017, 6, 243-249. [CrossRef]

37. Asociatia de Standardizare din Romania. Wheat Flour (original title in Rom.: Făină de grau). Romanian Standard 877:1996, 2 November 2011.

38. AACC. Method 38-12. In Approved Methods of the American Association of Cereal Chemists, 11th ed.; American Association of Cereal Chemists: St. Paul, MN, USA, 2000.

39. Man, S.M.; Paucean, A.; Calian, I.D.; Muresan, V.; Chis s, M.S.; Pop, A.; Muresan, A.; Bota, M.; Muste, S. Influence of fenugreek flour (Trigonella foenum-graecum L.) addition on the technofunctional properties of dark wheat flour. J. Food Qual. 2019, 2019, 8635806. [CrossRef]

40. Păucean, A.; Man, S.M.; Chiş, M.S.; Mureşan, V.; Pop, C.R.; Socaci, S.A.; Mureşan, C.C.; Muste, S. Use of pseudocereals preferment made with aromatic yeast strains for enhancing wheat bread quality. Foods 2019, 8, 443. [CrossRef]

41. Chiş, M.S.; Păucean, A.; Man, S.M.; Vodnar, D.C.; Teleky, B.E.; Pop, C.R.; Stan, L.; Borsai, O.; Kadar, C.B.; Urcan, A.C.; et al. Quinoa sourdough fermented with Lactobacillus plantarum ATCC 8014 designed for gluten-free muffins-A powerful tool to enhance bioactive compounds. Appl. Sci. 2020, 10, 7140. [CrossRef]

42. Seevaratnam, V.; Banumathi, P.; Premalatha, M.R.; Sundaram, S.P.; Arumugam, T. Studies on the preparation of biscuits incorporated with potato flour. World J. Dairy Food Sci. 2012, 7, 16. [CrossRef]

43. Bunea, A.; Rugină, D.O.; Pintea, A.M.; Sconţa, Z.; Bunea, C.I.; Socaciu, C. Comparative polyphenolic content and antioxidant activities of some wild and cultivated blueberries from romania. Not. Bot. Horti Agrobot. Cluj Napoca 2011, 39, 70-76. [CrossRef]

44. Chiș, M.S.; Păucean, A.; Stan, L.; Mureșan, V.; Vlaic, R.A.; Man, S.; Muste, S. Lactobacillus plantarum ATCC 8014 in quinoa sourdough adaptability and antioxidant potential. Rom. Biotechnol. Lett. 2018, 23, 13581-13591.

45. Socaci, S.A.; Socaciu, C.; Muresan, C.; Farcas, A.; Tofana, M.; Vicas, S.; Pintea, A. Chemometric discrimination of different tomato cultivars based on their volatile fingerprint in relation to lycopene and total phenolics content. Phytochem. Anal. 2014, 25, 161-169. [CrossRef] [PubMed]

46. El-Sayed, A.M. The Pherobase: Database of Pheromones and Semiochemicals. 2011. Available online: https://www.pherobase. com/ (accessed on 7 December 2020).

47. Acree, T.; Arn, H. Flavornet and Human Odor Space. Available online: http:/ / www.flavornet.org (accessed on 7 December 2020).

48. Pop, A.; Paucean, A.; Socaci, S.A.; Alexa, E.; Man, S.M.; Muresan, V.; Chis, M.S.; Salanta, L.; Popescu, I.; Berbecea, A.; et al. Quality characteristics and volatile profile of macarons modified withwalnut oilcake by-product. Molecules 2020, 25, 2214. [CrossRef] [PubMed]

49. Park, J.; Choi, I.; Kim, Y. Cookies formulated from fresh okara using starch, soy flour and hydroxypropyl methylcellulose have high quality and nutritional value. LWT Food Sci. Technol. 2015, 63, 660-666. [CrossRef]

50. Kelapure, N.N.; Rameshwar, H.; Jaju, R.H.; Amarjeet, N.; Satwase, A.N.; Avdhut, V.; Gutthe, A.V.; Tidke, S.S. Study on quality attributes of flaxseed flour supplemented cookies. Int. J. Pure Appl. Biosci. 2018, 6, 1439-1445. [CrossRef]

51. Mamat, H.; Hill, S.E. Structural and functional properties of major ingredients of biscuit. Mini Review. Int. Food Res. J. 2018, $25,462-471$.

52. Devi, K.; Haripriya, S. Pasting behaviors of starch and protein in soy flour-enriched composite flours on quality of biscuits. J. Food Process. Preserv. 2014, 38, 116-124. [CrossRef]

53. Wei, C.; Zhou, Q.; Han, B.; Chen, Z.; Liu, W. Changes occurring in the volatile constituents of flaxseed oils (FSOs) prepared with diverse roasting conditions. Eur. J. Lipid Sci. Technol. 2019, 121, 1800068. [CrossRef]

54. Pico, J.; Bernal, J.; Gómez, M. Wheat bread aroma compounds in crumb and crust: A review. Food Res. Int. 2015, 75, 200-215. [CrossRef]

55. Khouryieh, H.; Aramouni, F. Physical and sensory characteristics of cookies prepared with flaxseed flour. J. Sci. Food Agric. 2012, 92, 2366-2372. [CrossRef] 
56. Cambus, H.; Mikulec, A.; Gambus, F.; Pisulewski, P. Perspectives of linseed utilisation in baking. Polish J. Food Nutr. Sci. 2004, $13,21-27$.

57. Kaur, M.; Kaur, R.; Gill, B.S. Mineral and amino acid contents of different flaxseed cultivars in relation to its selected functional properties. J. Food Meas. Charact. 2017, 11, 500-511. [CrossRef]

58. Zouari, R.; Souhail Besbes, S.; Ellouze-Chaabouni, S.; Ghribi-Aydi, D. Cookies from composite wheat-sesame peels flours: Dough quality and effect of Bacillus subtilis SPB1 biosurfactant addition. Food Chem. 2016, 194, 758-769. [CrossRef]

59. Antoniewska, A.; Jarosława Rutkowska, J.; Pineda, M.M.; Agata Adamska, A. Antioxidative, nutritional and sensory properties of muffins with buckwheat flakes and amaranth flour blend partially substituting for wheat flour. LWT Food Sci. Technol. 2018, 89, 217-223. [CrossRef]

60. Ahmed, M.; Assem, N.H.A.; Nadia, M.; Fahim, J.S. Utilization of flaxseeds in improving bread quality. Egypt. J. Agric. Res. 2011, $89,241-250$.

61. El-Demery, M.; Mahmoud, K.F.; Bareh, G.F.; Albadawy, W. Effect of fortification by full fat and defatted flaxseed flour sensory properties of wheat bread and lipid profile laste. Int. J. Curr. Microbiol. App. Sci. 2015, 4, 581-598.

62. Hassan, A.A.; Rasmy, N.M.; Foda, M.I.; Bahgaat, W.K. Production of functional biscuits for lowering blood lipids. World J. Dairy Food Sci. 2012, 7, 1-20. [CrossRef]

63. Akl, E.M.; Mohamed, S.S.; Hashem, A.I.; Taha, F.S. Biological activities of phenolic compounds extracted from flaxseed meal. Bull. Natl. Res. Cent. 2020, 44, 27. [CrossRef]

64. Deng, Q.; Yu, X.; Ma, F.; Xu, J.; Huang, F.; Huang, Q.; Sheng, F. Comparative analysis of the in-vitro antioxidant activity and bioactive compounds of flaxseed in China according to variety and geographical origin. Int. J. Food Prop. 2018, 20, S2708-S2722. [CrossRef]

65. Bernacchia, R.; Preti, R.; Vinci, G. Chemical composition and health benefits of flaxseed. Austin J. Nutr. Food Sci. $2014,2,1045$.

66. Petersen, K.; Gmbh, G.; Kg, C. Flavour and fragrance analysis: Wondrous Vanilla. Column 2014, 10, 11-15.

67. Suri, K.; Singh, B.; Kaur, A.; Yadav, M.P.; Singh, N. Influence of microwave roasting on chemical composition, oxidative stability and fatty acid composition of flaxseed (Linum usitatissimum L.) oil. Food Chem. 2020, 326, 126974. [CrossRef]

68. Chiş, M.S.; Pop, A.; Paucean, A.; Socaci, S.A.; Alexa, E.; Man, S.M.; Bota, M.; Muste, S. Fatty acids, volatile and sensory profile of multigrain biscuits enriched with spent malt rootles. Molecules 2020, 25, 442. [CrossRef]

69. Chai, D.; Li, C.; Zhang, X.; Yang, J.; Liu, L.; Xu, X.; Du, M.; Wang, Y.; Chen, Y.; Dong, L. Analysis of volatile compounds from wheat flour in the heating process. Int. J. Food Eng. 2019, 15, 1-13. [CrossRef]

70. Starowicz, M.; Koutsidis, G.; Zieliński, H. Determination of antioxidant capacity, phenolics and volatile Maillard reaction products in rye-buckwheat biscuits supplemented with 3ß-D-rutinoside. Molecules 2019, 24, 982. [CrossRef] [PubMed]

71. Hidalgo, F.J.; Zamora, R. Formation of phenylacetic acid and benzaldehyde by degradation of phenylalanine in the presence of lipid hydroperoxides: New routes in the amino acid degradation pathways initiated by lipid oxidation products. Food Chem. X 2019, 2, 100037. [CrossRef] [PubMed]

72. Rajiv, J.; Indrani, D.; Prabhasankar, P.; Rao, G.V. Rheology, fatty acid profile and storage characteristics of cookies as influenced by flax seed (Linum usitatissimum). J. Food Sci. Technol. 2012, 49, 587-593. [CrossRef] [PubMed]

73. Austria, J.A.; Aliani, M.; Malcolmson, L.J.; Dibrov, E.; Blackwood, D.P.; Maddaford, T.G.; Guzman, R.; Pierce, G.N. Daily choices of functional foods supplemented with milled flaxseed by a patient population over one year. J. Funct. Foods 2016, 26, 772-780. [CrossRef]

74. Čukelj, N.; Novotni, D.; Sarajlija, H.; Drakula, S.; Voučko, B.; Ćurić, D. Flaxseed and multigrain mixtures in the development of functional biscuits. LWT Food Sci. Technol. 2017, 86, 85-92. [CrossRef]

75. Rangrej, V.; Shah, V.; Patel, J.; Ganorkar, P.M. Effect of shortening replacement with flaxseed oil on physical, sensory, fatty acid and storage characteristics of cookies. J. Food Sci. Technol. 2015, 52, 3694-3700. [CrossRef] [PubMed]

76. Aliani, M.; Ryland, D.; Pierce, G.N. Effect of flax addition on the flavor profile of muffins and snack bars. Food Res. Int. 2011, 44, 2489-2496. [CrossRef]

77. Ramcharitar, A.; Badrie, N.; Mattfeldt-Beman, M.; Matsuo, H.; Ridley, C. Consumer acceptability of muffins with flaxseed (Linum usitatissimum). J. Food Sci. 2005, 70, s504-s507. [CrossRef]

78. Rathi, P.; Mogra, R. Sensory evaluation of biscuits prepared with flaxseed flour. Int. J. Food Nutr. Sci. 2013, 2, 1-4. 